This article was downloaded by: [University College London]

On: 24 October 2014, At: 08:06

Publisher: Routledge

Informa Ltd Registered in England and Wales Registered Number: 1072954 Registered

office: Mortimer House, 37-41 Mortimer Street, London W1T 3J H, UK

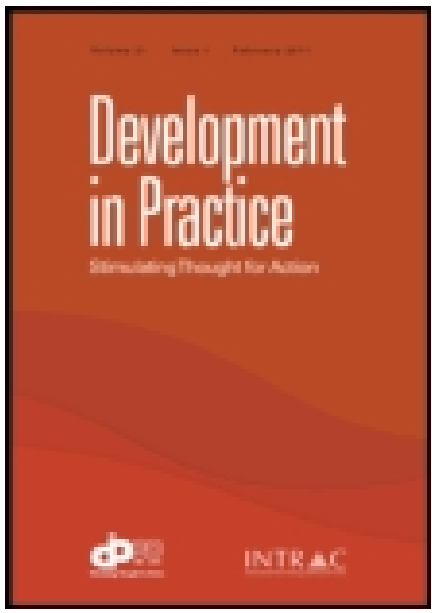

\title{
Development in Practice
}

Publication details, including instructions for authors and

subscription information:

http:// www.tandfonline.com/loi/ cdip20

\section{Time poverty, gender and well-being: lessons from the Kyrgyz Swiss Swedish Health Programme}

J ulian Walker

Published online: 18 Feb 2013.

To cite this article: J ulian Walker (2013) Time poverty, gender and well-being: lessons from the Kyrgyz Swiss Swedish Health Programme, Development in Practice, 23:1, 57-68, DOI: 10.1080/09614524.2013.751357

To link to this article: http:// dx.doi.org/ 10.1080/09614524.2013.751357

\section{PLEASE SCROLL DOWN FOR ARTICLE}

Taylor \& Francis makes every effort to ensure the accuracy of all the information (the "Content") contained in the publications on our platform. Taylor \& Francis, our agents, and our licensors make no representations or warranties whatsoever as to the accuracy, completeness, or suitability for any purpose of the Content. Versions of published Taylor \& Francis and Routledge Open articles and Taylor \& Francis and Routledge Open Select articles posted to institutional or subject repositories or any other third-party website are without warranty from Taylor \& Francis of any kind, either expressed or implied, including, but not limited to, warranties of merchantability, fitness for a particular purpose, or non-infringement. Any opinions and views expressed in this article are the opinions and views of the authors, and are not the views of or endorsed by Taylor \& Francis. The accuracy of the Content should not be relied upon and should be independently verified with primary sources of information. Taylor \& Francis shall not be liable for any losses, actions, claims, proceedings, demands, costs, expenses, damages, and other liabilities whatsoever or howsoever caused arising directly or indirectly in connection with, in relation to or arising out of the use of the Content.

This article may be used for research, teaching, and private study purposes. Terms \& Conditions of access and use can be found at http://www.tandfonline.com/page/termsand-conditions 
It is essential that you check the license status of any given Open and Open Select article to confirm conditions of access and use. 


\title{
Time poverty, gender and well-being: lessons from the Kyrgyz Swiss Swedish Health Programme
}

\author{
Julian Walker
}

Time poverty methodologies are a response to the failure of income-based measures of poverty to reflect gendered aspects of well-being. However, national time use surveys normally fail to examine issues around women and men's qualitative evaluation of their time uses, or the extent of their control over their own time. The result could be distorted policy responses which lose sight of the original intentions of time poverty as a tool to reveal gendered elements of wellbeing. This paper draws on the findings of a qualitative survey to asses a rural health promotion programme in Kyrgyzstan to demonstrate this point.

La pauvreté en temps, le sexe et le bien-être: les enseignements du programme kirghiz suisse suédois

Les méthodologies liées à la pauvreté en temps constituent une réponse à l'échec des mesures de la pauvreté basées sur le revenu pour traduire les aspects du bien-être liés au genre. Cependant, les études nationales sur l'utilisation du temps n'examinent pas en général les questions concernant l'évaluation qualitative par les femmes et les hommes des manières dont ils utilisent leur temps, ni la mesure du contrôle qu'ils exercent sur leur propre temps. Le résultat pourrait être des ripostes politiques déformées qui perdent de vue les intentions initiales de la pauvreté en temps comme outil visant à mettre à jour les aspects du bien-être liés au genre. Afin de démontrer cette observation, cet article s'inspire des conclusions d'une enquête qualitative menée pour évaluer un programme de promotion de la santé rurale au Kirghizistan.

Tiempo-pobreza, el género y el bienestar: lecciones del programa de Kirguistán Suiza Sueco Las metodologías tiempo-pobreza constituyen una alternativa ante lo insuficientes que resultan las medidas de pobreza basadas en el ingreso cuando se considera el aspecto de género en el bienestar. En general, las encuestas nacionales de uso de tiempo no abordan las evaluaciones cualitativas realizadas por mujeres y hombres en relación a su uso del tiempo, así como tampoco valoran el alcance del control que tienen sobre su tiempo. Por ello, los resultados obtenidos en estos casos podrían dar pie a la elaboración de políticas equivocadas, que ignoren la intención original de las medidas tiempo-pobreza, en cuanto medidas que evidencian el factor de género en el bienestar. Este artículo se basa en las conclusiones de un estudio cualitativo, realizado con el objetivo de evaluar un programa de promoción de la salud rural en Kirguistán, el cual fue llevado a cabo para demostrar la validez de lo anterior. 
Pobreza de tempo, gênero e bem-estar: lições do programa do Quirguistão Suíça Sueca As metodologias de pobreza do tempo são uma resposta ao fracasso de medidas da pobreza baseadas na renda em refletir aspectos do bem-estar relativos a gênero. Porém, as avaliações nacionais do uso do tempo normalmente deixam de examinar questões relacionadas à avaliação qualitativa do uso do tempo por parte de mulheres e homens ou a extensão de seu controle sobre seu próprio tempo. O resultado poderia ser o de respostas de política distorcidas que perdem de vista as intenções originais da pobreza do tempo como ferramenta para revelar elementos de bem-estar relativos a gênero. Este artigo baseia-se nos resultados de uma pesquisa qualitativa para avaliar um programa de promoção da saúde rural em Kyrgyzstan a fim de demonstrar esse ponto.

KEY Words: Gender and diversity; Labour and livelihoods - Poverty reduction; Social sector - Health

\section{Introduction}

Many new development concepts are developed explicitly in an attempt to ensure that development interventions keep an eye on promoting social justice, tackling inequality, and avoiding development agendas being co-opted to serve the interests of the status quo. However, there is a tendency for such concepts to become orthodoxies which are uncritically applied, in ways which misrepresent reality, and consciously or unconsciously serve to reinforce the very inequalities that they were intended to address.

Instances of a kind of declawing of development concepts abound. For example, despite the radical intentions of participatory research, participatory initiatives based on such research have often, in practice, exploited the labour and capital of the poor without expanding their space for decision-making and autonomy (Cooke and Kothari 2001). It is therefore important to constantly, and critically, re-examine development concepts and tools to protect their radical intentions.

This paper looks at emerging work on time poverty, as one such new development concept which aims to promote social justice, by making gendered experiences of poverty more visible. It goes on to argue, however, that the potential of this conceptual tool to contribute to social justice may be compromised if national time use surveys ignore issues about women and men's control over their time, and their own subjective evaluations of the quality of their time uses. This point will be illustrated using the findings of a gender analysis of a rural health promotion programme in Kyrgyzstan. The paper concludes by arguing that, before policy decisions are made on the basis of time use data, such data should be subject to qualitative analysis in order to ensure that incorrect assumptions are not made about the impact of time use changes on women and men's well-being.

\section{Time use surveys}

Time use surveys have become an increasingly prominent set of methods, gradually scaling up into national initiatives such as the first national Australian time use survey in 1992 (Castles 1994). By the mid-1990s international attention was focused on time use surveys to the extent that the Beijing Platform for Action called for national statistical agencies to conduct regular time use surveys (UN 1996, para. 206g). Currently time use survey tools have been adopted by a wide range of countries (the UN Statistics website lists 63). The growing application of time use surveys responds to feminist economists' call to both undertake research 
that values non-market activities, and to develop measures of poverty and well-being that better reflect gendered dimensions.

\section{Valuing of non-market activities}

The impetus for developing a research base on time use starts from the argument that the measurement of economic activities only through market and income-based measures (those typically used in Systems of National Accounts (SNAs)) is problematic because of the large amounts of hidden work and production missed (Elson and Cagatay 2000; Folbre 2006). Time use surveys are a valuable means to reveal informal sector activities, unpaid work such as subsistence agriculture, work done by contributing family workers, as well as reproductive (care) work in what is termed the household economy. Due to the predominant global gender division of labour, the majority of this invisible work is conducted by women, meaning that much of women's work is undervalued and not properly reflected in policy-making. One of the principal uses of time use surveys has therefore been to combat the underestimation of female labour force participation (Charmes 2006) and of the economic contribution of women more generally.

Time-use data is typically used to reveal the extent of work that is not included in SNAs by imputing monetary value to this work (Hirway 2005). This gives policymakers a better understanding of the impact of their interventions and, it can be argued, has also had a wider policy impact. For example the fact that the international SNAs has now been broadened to include some categories of unpaid work for the care of the household (Charmes 2006) can be in part attributed to the evidence provided through national time use surveys. Time use surveys have therefore played a critical role in "giving flesh to the feminist economics project of stretching the limits of the "economic"' (Esquivel et al. 2008, 109).

\section{Poverty, well-being, and time}

Another way in which time use data has been increasingly employed is to develop an understanding of time scarcity as a key aspect of poverty. Building on critiques of narrowly income based measures of poverty, time poverty analysis attempts to provide definitions and measures of poverty that go beyond income, to look at diminished well-being.

Well-being can be defined as "an interplay between the resources that a person is able to command; what they are able to achieve with those resources; and the meanings that frame these and that drive their aspirations and strategies" (McGregor 2006, 2). In this light, time poverty focuses on how the resources that people command determine what they are able to achieve in terms of rest and leisure as critical components of quality of life. A typical definition of time poverty, therefore, is where: "some individuals do not have enough time for rest and leisure after taking into account the time spent working, whether in the labor market, for domestic work, or for other activities such as fetching water and wood" (Blackden and Wodon 2006, 6).

In this light, time poverty measurements reveal the direct impact of changes in time use on well-being, with the additional advantage that time use is comparable across contexts, without encountering the kind of parity issues faced by income measures (Hirway 2005). Attempts have been made to aggregate these measures to the national level by developing time poverty lines, drawing on data from national time use surveys. Thus, for example, Lawson (2008) used time use data to develop time poverty lines in Lesotho, defined as a multiple of 1.5 of the median of hours worked in the country. 


\section{Gender and time poverty}

The focus on time use as an indicator of poverty builds on the argument that invisible work (in which, as discussed above, women predominate) demands significant time, and, when combined with participation in paid work, makes for very long days, with limited free, or leisure time. Women from poor households (who cannot, for example, pay for replacement services such as childcare if they take on paid work) are particularly burdened with such time demands. Thus as Folbre notes (2006, 184), "Increased participation in paid employment is often purchased at the expense of time once devoted to personal care, sleep and leisure". As the typical gender division of labour means that women are more commonly expected to undertake unpaid care work in the household, poor women who participate in paid work still have to spend time on unpaid care work, which is conceptualised as a "household overhead" (Harvey and Taylor 2000) or "reproductive tax" (Palmer 1995).

The gendered nature of time poverty can be reinforced by the tendency for policymakers to assume that women have more free time than they actually do, resulting in interventions which increase demands on women's paid and unpaid labour inputs, as was the case in many structural adjustment packages (Elson 2002; Moser 1993). Thus, if poverty is defined to encompass scarcity of time, then many interventions that have been ostensibly designed to alleviate poverty have in fact contributed to increasing it. Data collection on time use and evidence to indicate how interventions can exacerbate many poor women's lack of time can be a critical input in critiquing policies which instrumentalise women as an expandable labour force, or as carers and volunteers, without recognising the impact on their well-being.

\section{Methodological challenges for time poverty measurements}

However, while time poverty has great potential for revealing gendered aspects of inequality and ill-being, its scope for this depends very much on how it is defined and measured.

First, defining time poverty as a pure lack of free or uncommitted time is problematic, due to the loss of focus on the choices that are available to women and men about how they use their time. For example, one of Lawson's findings in Lesotho is that wealthier, and better educated, individuals are more likely to be "time poor". In particular he notes that as women "become more educated they appear to take on greater numbers of formal work, but domestic duties are not proportionately reduced" $(2008,20)$. The result could be a distorted understanding of poverty as, in this case, more opportunities to engage in formal work are taken to lead to increases in poverty, which contradicts conceptualisations of poverty as a lack of choice, or freedom. It is therefore important to recognise that there is an element of choice in time use which means that a busier day is not necessarily the same as time poverty, in much the same way that Sen (1993) has pointed out that, unlike a person who is undernourished because they cannot afford food, a person who is undernourished because they are choosing to fast is not "poor".

The element of choice in relation to time poverty is developed by Goodin et al. (2005), who use the concept of discretionary time in their analysis of Australian time use survey data to address the apparent anomaly that people in two adult, childless, double income households often have less free time than people in other household types. This, they argue, is because a "time pressure illusion" is created by the choices that people make to spend more time on tasks (personal care, and paid and unpaid labour) than they have to (in order to maintain defined minimum living standards).

One way of responding to such an illusion is by making linkages between time poverty and other parameters of poverty. Charmes defines time poverty as a "lack of time due to multiple 
timetables (domestic work, care work, non-market economic activity) resulting in time poverty and low monetary income" (2006, 40). Burchardt (2008) similarly approaches time poverty as something that is experienced by those who could avoid income poverty only by incurring time poverty. In this vein, she focuses on time and income "capability", as the range of possible time and income combinations that individuals could have, in the context of social policy systems which affect these choices.

In addition to debates about how time use poverty should be defined there has been much discussion about how relevant data should be collected to properly reveal the incidence of time poverty, with competing claims for self-completed time use diaries, activity lists, or facilitated diaries (UN 2005; Esquivel et al. 2008). The issue of how to standardise classifications of time use has been addressed by the United Nations-sponsored Trial International Classification of Activities for Time-use Statistics (ICATUS), which breaks down time use into a range of agreed categories (Bediako and Vanek 1998). When dividing time into categories "it is particularly difficult to capture 'simultaneous' tasks" (Blackden and Wodon 2006, 1) and, as, Kes and Swaminathan (2006) note, due to time pressure, women in particular often undertake tasks simultaneously. Furthermore, as most time use information is captured through self-completed time use diaries, the fact that women and men may internalise gender norms about time use and customary tasks could mean that a clear distinction between care and leisure, or work and leisure, may not emerge. Thus for example, as Folbre (2006) notes much of the time that women report as leisure is accompanied by childcare constraints.

Despite debate about how best to undertake time use surveys to identify and measure time poverty, there is a growing consensus on the importance of measuring time use in, for example, highlighting the importance of basic infrastructure for well-being (Lawson 2008; Kes and Swaminathan 2006), or the need for social policy to factor in support to care giving roles, in order to ensure the well-being of both care givers and receivers (Folbre 2004).

However, like many other development concepts, time poverty runs the risk of being distorted or used in ways which contradict their original intention. This can be illustrated by the findings of a gender analysis that the author undertook on a primary health promotion project in Kyrgyzstan in 2010.

\section{The KSSHP}

The Kyrgyz-Swiss-Swedish Health Project (KSSHP) is part of the wider Manas Health Reform Programme, conducted by the Ministry of Health of the Kyrgyz Republic since the mid-1990s, with donor support. The KSSHP has been funded by the Swiss Agency for Development and Cooperation (SDC) since 2000, with the Swedish International Development Agency (Sida) since 2006, and implemented by the Swiss Red Cross (SRC).

The main component of the KSSHP is the development of health promotion systems in rural areas as a response to their poor coverage by healthcare systems since independence. KSSHP developed a community centred health promotion strategy, the Community Action for Health (CAH) model, which operates through the creation of Village Health Committees (VHCs) during Participatory Appraisal (PRA) exercises, and the subsequent support of these VHCs by the project and its network of health trainers, with government rural health institutions and staff, such as the village Primary Health Care workers.

VHC members are elected during initial PRA exercises in each community, and subsequently work on a voluntary basis to attend health training and carry out "health actions", many of which centre on disseminating health information to other community members. Typical campaigns are, for example, awareness raising on the need to use iodised salt to avoid goitre (an endemic problem in this landlocked country) or campaigns on personal protection for those 
working with animals to avoid brucellosis (a debilitating but avoidable disease which is caught through close contact with sheep). In addition the project used stimulation funds to support the VHCs in developing income-generating activities to both raise funds for VHC work and to support the livelihoods of VHC members and other villagers.

\section{Gender analysis of the KHSSP}

In 2010, as an input to the wider evaluation of the project, the author undertook a gender analysis of the impact of the project. The request for this study came from the SDC, as one of the project's main donors. In line with the SDC's policy on gender equality they wished to ensure that the project was promoting gender equality and the empowerment of women. One of their concerns was the potential impact of the project on women's time poverty, given that the project was drawing principally on women's voluntary (unpaid) inputs in an area (healthcare) which is generally understood as a women's concern in Kyrgyzstan.

The gender analysis included (in addition to a desk review, questionnaire surveys across all of the project's VHCs, and a series of interviews with project stakeholders from government institutions and donor organisations) a qualitative survey, based on a series of focus group sessions with VHCs in villages in Batken, Chui, and Naryn oblasts (three administrative districts in the south, north, and centre of the country). The sessions were conducted with the KSSHP Deputy Project Coordinator and in some cases with local health workers and project staff. They were structured around a discussion guideline, and a group exercise designed to explore the impact of project activities on the gender roles of VHC members, using the Development Planning Unit gender analysis framework, which builds on the Moser gender analysis framework (Moser 1993).

The findings of this study, presented in more detail below, were that the project's reliance on women's time inputs through voluntary work was significant. However, feedback from women involved in group discussions during the survey was that they did not interpret this as exposing them to time poverty. This was firstly because of the quality of the time use (as they value the time spent on VHC activities both intrinsically, and also because it leads to opportunities to move into other valued activities such as public decision-making at the village level), and secondly because of their increased control of time use (as their involvement in VHC activities gives them a basis to negotiate with other household members on how they spend their time).

During the survey, issues about the project's time demands on women and men, which could shed some light on its impact on time poverty, began to emerge. In all of the VHCs visited during the fieldwork, membership in general, as well as on the board, was much lower for men, and in a number of the VHCs visited there were no male members at all (a pattern which was confirmed by the project's annual report for 2009 which notes that 84 per cent of board members are women). While there is no data for overall membership the survey suggested that this is even more heavily made up of women, and furthermore it was clear that women members tend to be much more active in the day-to-day activities of the VHCs.

Participants gave a number of explanations for why men are less active on VHCs, a common response being that men "do not have time" for health promotion activities. However, on further discussion it was agreed (by women and men) that women do not have more free time than men (and in fact one of the reasons given for women's limited involvement in local politics was that they do not have time). Thus it appeared that the issue is not that men do not have time, but that undertaking (unpaid) community health work is not viewed as a suitable use of men's time.

Typically, members spend between seven hours and a day and a half per month on VHC activities, and once or twice a year (more frequently for leaders) they spend a day attending Raion (sub-district) level meetings. Furthermore, many of the villages in the mountainous 
areas of the north of the country are widely dispersed and in some cases (for example in the high altitude village of Birinchi May) members had to travel up to two hours on horseback to reach the health centres where the VHC meetings are held. Members also travel long distances to attend the VHC meetings when they are living in the high pastures (jailo) during the summer grazing period.

In this light, the fact that women predominate in VHC activities, contribute more time to them than male VHC members, and spend a significant amount of time travelling to and participating in VHC activities in a voluntary capacity, could be taken to mean that the project is inadvertently contributing to women's time poverty. Furthermore it would appear that the project is doing so by unwittingly conspiring with gender norms around women's role as carers and around the assumption that men, as breadwinners, should only use their time where this generates income.

However, while some focus group participants said that VHC activities eat into their time, the response of the majority of VHC members did not suggest that they felt the project was exposing them to time poverty, for a number of reasons.

First, while some women VHC members involved in the survey said that the project made additional demands on their time, most participants in discussion groups said that they plan ahead to balance their various responsibilities with VHC activities (although they agreed that this made for a "longer day" at times). Secondly, many said that they prefer to spend time on VHC activities than "just sitting at home", implying that they prioritise VHC work over some forms of leisure time. Finally, some women said that, because it is seen as important, they can ask family members to take on their agricultural work or childcare responsibilities to free up their time for the VHC.

Thus, while VHC members may have to sacrifice other activities in order to make time for VHC work, it appears that they prioritise time spent on the VHC and are willing to plan and juggle other activities to make time for it. Frequent stories raised during the survey sessions of women who had fought with family members to be allowed to participate in the committees are evidence of the value that women VHC members give to this role. Many women had faced resistance from other household members (principally their husbands or fathers-in-law) when they wanted to join the VHCs. In some cases this changed when the impact of their work became increasingly recognised and valued by the community, though in others they faced continued resistance and struggled to be allowed to attend VHC meetings, and some had dropped out of the committees due to family resistance. However, those women who have been able to assert their right to work on the VHC in the face of family resistance said that they have been able to increase their autonomy in relation to authority from other household members, often with the moral support of other VHC members. In addition a number said that the health information that they share with other household members has increased their status in their households and allowed them to have discussions about health issues with other household members (such as fathers-in-law) in ways which would not previously have been possible.

One of the main arguments from household members who resisted women joining the VHC was that they should be doing their housework, or should not be wasting their time on unpaid community work. Thus by asserting their right to work on the VHCs, women are asserting more control over their own time, and the status and importance of their VHC work allows them to do this, giving them the space to de-prioritise reproductive (childcare and housework) and productive (farm work) tasks, or to share these activities with other household members who would not normally do them. Thus, the negative impacts of women's time poverty need to be set against the positive impacts on women's ability to exert control over their time use.

In addition, discussions indicated that women are willing to invest extra time in activities which they feel that they are deriving personal or communal benefits from, and to equate 
these time demands to those associated with drudgery or non-negotiable exploitation of their time is not helpful. One such benefit that made women value time on VHS work was the space that it gave them to participate in public life. Although this was not an explicit strategy of the project, membership in VHCs created a space for women's participation in the public life of villages which did not previously exist. Kyrgyzstan has a low level of women's participation in public life, and particularly in local government (Bagdasarova, Gorborukova, and Moldoshev 2008). This could explain, in part, the popularity of VHC membership amongst village women, as the project has created the space for women to incrementally expand their role in local politics and decision-making to an extent that is not traditional in most of the villages. To a large extent this has been possible because health care, unlike other sectors such as the management of water resources, is what has been termed an "uncontested domain", or an area of public life into which is not controversial for women to expand (Jayapadma and Johnson 2005) as they are traditionally associated with the health sector, and so decision-making role in this sector is therefore not threatening to the status quo.

\section{Implications for time poverty analysis}

The KSSHP case presents a situation in which the project's intervention put increasing time pressure on its (primarily female) volunteers without financial returns. Therefore, if a narrow interpretation of time poverty were to be adopted, this would appear to be an example of an intervention which, by failing to address gendered norms about women's social roles, had exacerbated their time poverty. However, if the intervention is examined in line with a wider understanding of poverty, which incorporates different groups of women and men's agency in identifying the aspects of well-being that they value, then quite different conclusions would be drawn about the project's impact on poverty and empowerment. Therefore the definition of time poverty should not simply be about a linked scarcity of time and income, but also need to factor in an evaluation of the quality of time use and about women and men's control over their own time.

A broader definition of time poverty, addressing quality and control of time uses, has implications for the methods that are used to undertake time use surveys. A review of national time surveys on the UN Statistics website, using methodologies such as the UN Trial International Classification of Activities for Time Use Statistics (ICATUS), the Harmonised European Time Use Surveys (HETUS) (EUROSTAT 2008), and the UN Statistics manual for time use survey (UN 2005), indicates that their primary focus is quantitative assessment of different activity categories that groups of women and men spend time on, to identify changing patterns of time use.

However, most time use surveys exclude dimensions of the experience of time, such as "degrees of freedom in deciding whether or not we take up certain tasks, differing intensity in performing activities, stressing/ relaxing ways of combining activities, power relations, love and affection" (Esquivel et al. 2008, 128). The KSSHP case shows how ignoring some of these dimensions could lead to conclusions that distort an understanding of women's empowerment and well-being, and therefore lead to inappropriate policy responses.

\section{Quality of time}

Focusing only on the division of time into different task-based categories does not give us any insight into the experience of carrying out these tasks, the ways in which women or men prioritise them, and which of them, given the opportunity, they would like to do more or less of. 
Despite this limited focus on the quality of time, it is suggested that time use data can be used to develop indicators of well-being. Hirway (2005) suggests that one indicator of well-being developed on the basis of time use surveys could be the proportion of time spent on "drudgeries" as a percentage of total time. However, what needs to be clarified here is what constitutes drudgery, and who defines drudgery in each context. If certain tasks or activities (such as water or firewood collection, caring roles, or housework) are classified as drudgeries, this should surely be based on the expressed opinions of women and men conducting these tasks, and their lived experience of doing so.

In the Kyrgyz case it was clear that women valued the time spent on VHC activities, and although it was unpaid work, they did not see it as drudgery. In this light, leisure time is not the only kind of time use that people might seek to expand, and the motivation for expanding non-leisure related uses of time is not always increased income, in the vein of the trade-off between income and free time highlighted by Burchardt (2008).

Furthermore, if time poverty is understood simply as a lack of free time, the assumption is that more free time is necessarily positive. In practice, if people do not have the opportunities or resources needed to use free time in ways that they value, an excess of free time can be a negative experience. In the Kyrgyz case many of the VHC members valued the fact that the health promotion activities gave them opportunities for social engagement rather than "just staying at home", implying that free or leisure time was not always valued in the absence of stimulating activities or social engagement.

Methodologies have been developed for time use survey which factor in an evaluation of the qualitative experience of time. The UN Statistics manual on time use survey raises the issue of subjective dimensions of time use (UN 2005), citing the work of Haraldsen (2000), who proposes a list of seven questions for time use dairies to classify experiences of the different activities recorded. These include questions such as "Have you reported any activities that you would rather not have done had it not been necessary in order to fulfil daily tasks?", and "Did any of the activities you have reported lead to new social contacts or to better contact with people you already know?" (Haraldsen 2000, 5).

However, while such methods are available, the UN manual also goes into some detail in highlighting the data collection difficulties of factoring in this type of subjective information, and remarks that subjective dimensions of time use "are often less essential survey objectives of a general-purpose national time use data collection, but may be important in specific applications, especially quality of life issues" (UN 2005, 41).

In practice, most national time use surveys do not attempt to address subjective assessments of the quality of time by respondents at all, and where they do, it is in a limited or simplified form. For example, the diary format used by the Australian time use survey asks respondents at the end of the two-day diary exercise to rank "In general, how satisfied or dissatisfied are you with the way you spent your time over the last two days?", but does not ask respondents to break this down by activity, thereby giving only a very general evaluation of the experience of time.

\section{Control over time}

Another problem with seeing time poverty as a lack of free time is that it does not factor in the choices open to people about how they use their time. Approaches such as distinguishing free time from "discretionary time" highlight the element of choice in time use. However, they may also overstate the choices available to people.

Discretionary time is defined as the time available for people to "do with as they please ... after life's necessities have been taken into account" (Goodin et al. 2005, 54). This implies that 
the lack of choice that constitutes time poverty stems from the time needed to fulfil basic necessities (care, unpaid reproductive work in the household, etc.). However, addressing life's necessities is usually not the only limit to people doing "as they please" with their time. In fact social norms and power relations also limit the ways in which different groups of women and men, and girls and boys, are able to exercise autonomous choices, or agency, over how they use their discretionary time.

Authors concerned with intra-household decision-making processes have repeatedly pointed out that household members' interests are frequently in conflict, and that hierarchical power relations between different household members can place limits on autonomous decisionmaking by some household members (Sen 1990; Kandiyoti 2007). Furthermore, it has been pointed out that one arena in which such hierarchical decision-making is expressed is time use, as social norms in many contexts allow senior household members to demand time inputs from other household members (wives, children) on unpaid productive work in agriculture, or on unpaid care work in the home (Folbre 1986, 2004). Thus, the minimum time inputs that many women and men have to make are not only determined by what is necessary to sustain the living standards for themselves and their households, but are also determined by social expectations, gender norms, and the time inputs that they are expected to make on behalf of other household members. In the KSSHP case it was clear that an important factor in relation to women's time use was the space to negotiate control over their own time with other household members. Thus if an assessment of control over time was factored in to time assessments, the women who were forced to drop out of the project by other household members (giving them more "free time") could actually be considered more "time poor".

A number of authors have discussed this issue (e.g. Burchardt 2008). However, as with the issues of quality of time discussed above, there does not seem to be a clear translation of conceptual points about control over time into the tools and methods that underpin most national time use surveys, meaning that lack of control over time is not reflected in data on time poverty. When discussing particular activities, many time survey tools require the specification of "for whom" activities were done (UN 2005; EUROSTAT 2008). However indicating "for whom" activities were carried out does not give insights into the level of coercion or free choice that determined participation in an activity. Unpacking the control and choice that women and men have over their time is also made complex by social norms about altruism and hegemonic gender relations which might mean that women and men do not question or acknowledge constraints to control over their time. However, although this is a complex task, there is a well-established field of study around issues of autonomous agency and empowerment, which has led to the development of tools designed to assess women and men's control over factors such as income, microcredit, or decision-making, and these could equally be applied to women and men's control over time.

\section{Implications}

There are a number of implications about how time use surveys are implemented in practice. Time use survey tools and the concept of time poverty have made crucial contributions in highlighting the gendered nature of inequalities in time demands. However, a more nuanced understanding and interpretation of data is necessary to ensure that time use studies do not result in policies which ignore people's own evaluation of their time use, and thus sideline issues which are critical for understanding their levels of well-being, such as the extent of control that different groups of women and men have over their time, and the value that they attribute to different time uses. 
One danger of ignoring people's own understanding and values in relation to time use is the possibility of developing policies which instrumentalise people's time for ends that do not necessarily promote their well-being. Thus, for example, Charmes argues that women are more time poor then men because of the multiple tasks that they are expected to balance, and thus "policies oriented toward an alleviation of female time budgets can have major impacts on resources derived from income-generating activities due to an increased amount of time dedicated to them, or also on child health thanks to an increased amount of time dedicated to care" $(2006,67)$. However, this seems to assume that women's time should be freed up so they can participate more in paid work or in childcare, and therefore runs the risk of instrumentalising women. Policy approaches need to be grounded in people's own evaluation of time and well-being and reflect their own priorities about how they wish to invest their time.

The KHSSP survey was a project level, qualitative survey, but this does not mean that a similar qualitative assessment of time use is not applicable at the level of national time use surveys. As discussed above the UN (2005) manual proposes ways in which qualitative assessments of time use can be factored in to surveys, but the fact that such approaches are rarely implemented perhaps relates more to lack of political will to put them into practice than to their complexity and expense, particularly given that the political support to undertake time use surveys at all is already a struggle (Esquivel et al. 2008). What needs to be made clear, therefore, is the value of developing a more nuanced, and person-centred, interpretation of time use, which could use less resourceintensive methods, such as the use of targeted qualitative research to interpret wider quantitative time use surveys. Without such interrogation of data, the danger is that invalid assumptions will be made about the linkages between different time uses and people's well-being, and that antipoverty interventions based on these will be misguided.

\section{References}

Bagdasarova, N., G. Gorborukova, and A. Moldoshev. 2008. Kyrgyz Republic: Country Gender Assessment in the Sphere of Politics 2008. Report Produced for the President's Administration of the Kyrgyz Republic with Support from the Swedish International Development Cooperation Agency, and the UN Gender Theme Group United Nations Development Programme.

Bediako, G., and J. Vanek (of the Statistics Division, United Nations New York). 1998. Trial International Classification of Activities for Time-use Statistics. Paper Presented at the International Conference on Time Use, University of Luneberg, April 22-25.

Blackden, M. C., and Q. Wodon. 2006. "Gender, Time use and Poverty: Introduction.” In Gender, Time use, and Poverty in sub-Saharan Africa. World Bank Working Paper No. 73, edited by M. C. Blackden and Q. Wodon, 1-10. Washington DC: World Bank.

Burchardt, T. 2008. Time and Income Poverty. CASE Report 57. London: Centre for Analysis of Social Exclusion (CASE), London School of Economics.

Castles, I. 1994. How Australians use their Time. Canberra: Australian Bureau of Statistics, ABS Catalogue No 4153.0.

Charmes, J. 2006. "A Review of Empirical Evidence on Time use in Africa from UN Sponsored Surveys." In Gender, Time use, and Poverty in sub-Saharan Africa. World Bank Working Paper No. 73, edited by M. C. Blackden and Q. Wodon, 39-72. Washington DC: World Bank.

Cooke, B., and U. Kothari. 2001. "The Case for Participation as Tyranny." In Participation: The new Tyranny?, edited by B. Cooke and U. Kothari, 1-15. London: Zed Books.

Elson, D. 2002. "Gender Justice, Human Rights and Neo-Liberal Economic Policies." In Gender Justice, Development and Rights, edited by S. Razavi and M. Molyneux, 78-114. Oxford: Oxford University Press.

Elson, D., and N. Cagatay. 2000. "The Social Content of Macroeconomic Policies." World Development 28 (7): 1347-1364. 
Esquivel, V., D. Budlender, N. Folbre, and I. Hirway. 2008. "Explorations of Time use Surveys in the South." Feminist Economics 14 (3): 107-152.

EUROSTAT. 2008. Harmonised European Time use Surveys 2008 Guidelines. EUROSTAT Methodologies and Working Papers. Luxembourg, European Commission.

Folbre, N. 1986. "Hearts and Spades: Paradigms of Household Economics." World Development 14 (2): 245-255.

Folbre, N. 2004. "A Theory of the Misallocation of Time." In Family Time: The Social Organization of Care, edited by N. Folbre and M. Bittman, 7-24. London: Routledge.

Folbre, N. 2006. "Measuring Care: Gender, Empowerment, and the Care Economy." Journal of Human Development 7 (2): 183-199.

Goodin, R., J. Rice, M. Bittman, and S. Saunders. 2005. "The Time-Pressure Illusion: Discretionary Time vs Free Time." Social Indicators Research 73: 43-70.

Haraldsen, G. 2000. Framework for Data Collection on Time-use: Relating Objectives, Design \& Resources. Paper Presented at Gender Issues in the Measurement of Paid and Unpaid Work, Expert Group Meeting on Methods for Conducting Time-use Surveys, United Nations Secretariat, Statistic Division, 23-27 October, in New York.

Harvey, A. S., and M. E. Taylor. 2000. “Time use.” In Designing Household Survey Questionnaires for Developing Countries, Lessons from 15 Years of the Living Standards Measurement Survey, edited by M. Grosh and P. Glewwe, 249-272. Washington DC: The World Bank.

Hirway, I. 2005. "Measurements Based on Time use Statistics: Some Issues." Paper Presented at the Conference on Unpaid Work and Economy: Gender, Poverty and Millennium Development Goals, Levy Economics Institute, October 1-3, in New York.

Jayapadma, R. V., and L. T. Johnson. 2005. "Targeting Strategic Gender Needs Through Practical Gender Needs: The Experience of Gram Vikas in Water and Sanitation." In Towards Gender Equality: Capitalization of SDC Experience in Gender Mainstreaming, edited by C. Levy, N. Taher, C. Vouhé and J. Walker, 28-31. Bern: Swiss Development Cooperation.

Kandiyoti, D. 2007. "Bargaining with Patriarchy." Gender and Society 2 (3): 274-290.

Kes, A., and H. Swaminathan. 2006. "Gender and Time Poverty in sub Saharan Africa." In Gender, Time use, and Poverty in sub-Saharan Africa. World Bank Working Paper No. 73, edited by M. C. Blackden and Q. Wodon, 13-38. Washington DC: World Bank.

Lawson, D. 2008. A Gendered Analysis of Time Poverty: The Importance of Infrastructure. UK, Economic and Social Research Council Global Poverty Research Group Working Paper GPRG-WPS-078.

McGregor, J. A. 2006. Research Well-Being: From Concepts to Methodology. WeD Working Paper 20, ESRC Research Group on Well-Being in Developing Countries.

Moser, C. 1993. Gender, Planning and Development: Theory, Practice and Training. New York: Routledge.

Palmer, I. 1995. "Public Finance from a Gender Perspective.” World Development 23 (11): 1981-1986.

Sen, A. 1990. "Gender and Cooperative Conflicts." In Persistent Inequalities: Women and World Development, edited by I. Tinker, 123-149. New York: Oxford University Press.

Sen, A. 1993. "Capability and Well-Being." In The Quality of Life, edited by M. Nussbaum and A. K. Sen, 30-53. Oxford: Clarendon.

UN (United Nations). 1996. Platform for Action. Outcome of The United Nations Fourth Conference on Women, in Beijing, China, September 1995.

UN. 2005. Guide to Producing Statistics on Time use: Measuring Paid and Unpaid Work. United Nations Department of Economic and Social Affairs, Statistics Division, New York.

\section{The author}

Julian Walker is a Lecturer and Course Director at the Development Planning of Unit of University College London, who undertakes consultancy and research in the fields of gender equality and social development. <Julian.walker@ucl.ac.uk> 